ISSN:

Print - $2277-0755$

Online - $2315-7453$

(c) FUNAAB 2016

Joumal of

Aqricultural

Science

and Environment

\title{
ECONOMIC CONTRIBUTION OF WILDLIFE TO BUSHMEAT MARKETS IN IBADAN, OYO STATE
}

\subsection{ODUNTAN ${ }^{1}$, J.A. SOAGA1 A.L.A. SHOTUY ${ }^{1}{ }^{1}$ O.A. AKINTUNDE ${ }^{1}$ AND T.0. OLAREWAJU ${ }^{2}$}

1D epartment of Forestry and Wildlife Management

Federal University of Agriculture, Abeokuta, O gun State, Nigeria

Comesponding Author: oladapo.oduntan@ yahoo.com

\begin{abstract}
This paper examined the economic contribution of wild animals to bushmeat trade in Ibadan, Oyo State, Nigeria. Five prominent bush meat markets in Ibadan and its suburb were used for the study. The selection was based on the high intensity of bush meat marketing operations identified with the markets. All sellers in each market visited were interviewed which sum up to forty four respondents. Data were collected using structured questionnaire. Budgetary analysis was done to calculate costs and return of the bushmeat sellers. Income on mammals had the highest $(\$ 5,755,600)$ per annum followed by the income on birds ( $\$ 858,000$ ) per annum and reptiles ( $\$ 182,000)$. In the same pattern, percentage contribution indicates that mammals contributed $84 \%$ of the total income, while wild birds contributed $12 \%$ of the total income and reptile $3 \%$. The net profit realized from the sales of mammals was $\$ 4,979,000$ and $\$ 180,900$ for wild birds. Cost and return analysis showed that sale of bushmeat is a profitable venture. In addition, mammals contributed more to the economy of the market than other two classes of animal found in the bushmeat market.
\end{abstract}

Keywords: Wild Animals, Nutrition, Bush meat, Wild Birds.

\section{INTRODUCTION}

Bushmeat is an African term for the meat of wild animals. Although duikers (small antelope), rats, porcupines and monkeys are most commonly eaten, bushmeat can be any type of terrestrial wild animal, from snails to elephants. Also, some amphibious or semiaquatic freshwater animals, such as frogs, turtles and crocodiles, are also regarded as bushmeat.

These wild animals are captured by indigenous people for income and subsistence (Cowlishaw, $\&$ al., 2004). Bushmeat is an important source of protein, widely con- sumed in both rural and urban areas (Wilkie and Carpenter, 1999). Bushmeat provides an equivalent and in some cases greater quality food than domestic meat of high protein and low fat (Hoffman, 2008). Malaisse and Parent (1982) established that bushmeat contains more protein than meat from domestic animals (such as Sheep, Pig). Ajayi (1971) recommended the domestication of rodents as a source of protein. Wildlife hunting is encouraged by high prices of these animals, which have led hunters to maintain supply from ever-decreasing wildlife populations. Studies on hunting and bushmeat trade have been conducted in several West and Central 
African countries but not many of such studies in Nigeria (A pe Aliance, 1998). The magnitude of exploitation and consumption however varies from one place to the other and is determined principally by its availability, but this is also influenced by government control on hunting, socio economic status and cultural prohibitions (Asibey, 1977). Bush meat has been part of the local diet for centuries (G rubb et al., 1998). Ajayi in 1971 reported that wild animal consumption among rural people in Nigeria's rainforest was $20 \%$ of their total animal protein intake compared to the $13 \%$ for the whole country. The protein content of bushmeat ranges from $16-55 \%$ compared to $11-20 \%$ for domestic animals (Ajayi \& Tewe 1983; Falconer 1990).

The author further noted that wild animals have higher carbohydrate contents (ranging from $1 \%$ in river $\log$ to $6 \%$ in forest genet) than domesticated as exemplified by $0.8 \%$ in pork and 1.3\% in mutton. Moreover, the same study reported 16 - 55\% protein content in bush meat compared to 11 - 20\% for domestic animals.

Snails for example provide a good source of protein, low in fat and are exceptionally high in iron, calcium and vitamins $\mathrm{B}$ (O duntan \& al, 2014). In addition, bush meat is often a good source of minerals and vitamins. The meat is sometimes recommended by medical doctors to improve patient's health conditions. D eckers (2003) estimated the monthly wild life harvest by licensed resident hunters in the deciduous and rainforest region of Nigeria during the raining season in year 2000. The study revealed that the animals most commonly harvested in the rain forest region are snails, squirrel, giant rats, guinea fowl, bats, cane rats, porcupine and chicken in that order.

The bush meat trade is perceived as a major threat to wild animal population in the tropics. There is little information in the literature about the organization of the trade or those involved, thus hindering the development of effective conservation policy (Guy \& al., 2004). It is also on record that bush meat extraction in Africa is exceptionally high and West Africa in particular is noted for severe hunting of game animals, leading to extinctions of some animal species (Oates et al., 2000; Brashares \& al., 2001) Most previous work has focused on the biological rather than the socio economic aspects of the trade, surprisingly little is known about the structure and performance of the market. This lack of knowledge is a significant obstacle to the conservation management of the bush meat trade because the development of effective management policies require a comprehensive understanding of how bushmeat markets operate (Samantha \& al., 2003). Hence this paper studied the economic contribution and market share of the classes of wild animals in major bushmeat markets of Ibadan, O yo State, Nigeria.

\section{METHODOLOGY}

Study Area

This study was done in Ibadan and its suburb (Figure 1). Ibadan at longitude $702^{\prime}$ and $7040^{\prime} \mathrm{E}$ and latitude 3o 35' and 4o $10^{\prime} \mathrm{N}$ is the largest indigenous city in tropical Africa and it is the capital of Oyo State, Nigeria. Ibadan is $128 \mathrm{~km}$ north-east of Lagos and $345 \mathrm{~km}$ south-west of Abuja, the Federal Capital Territory. 


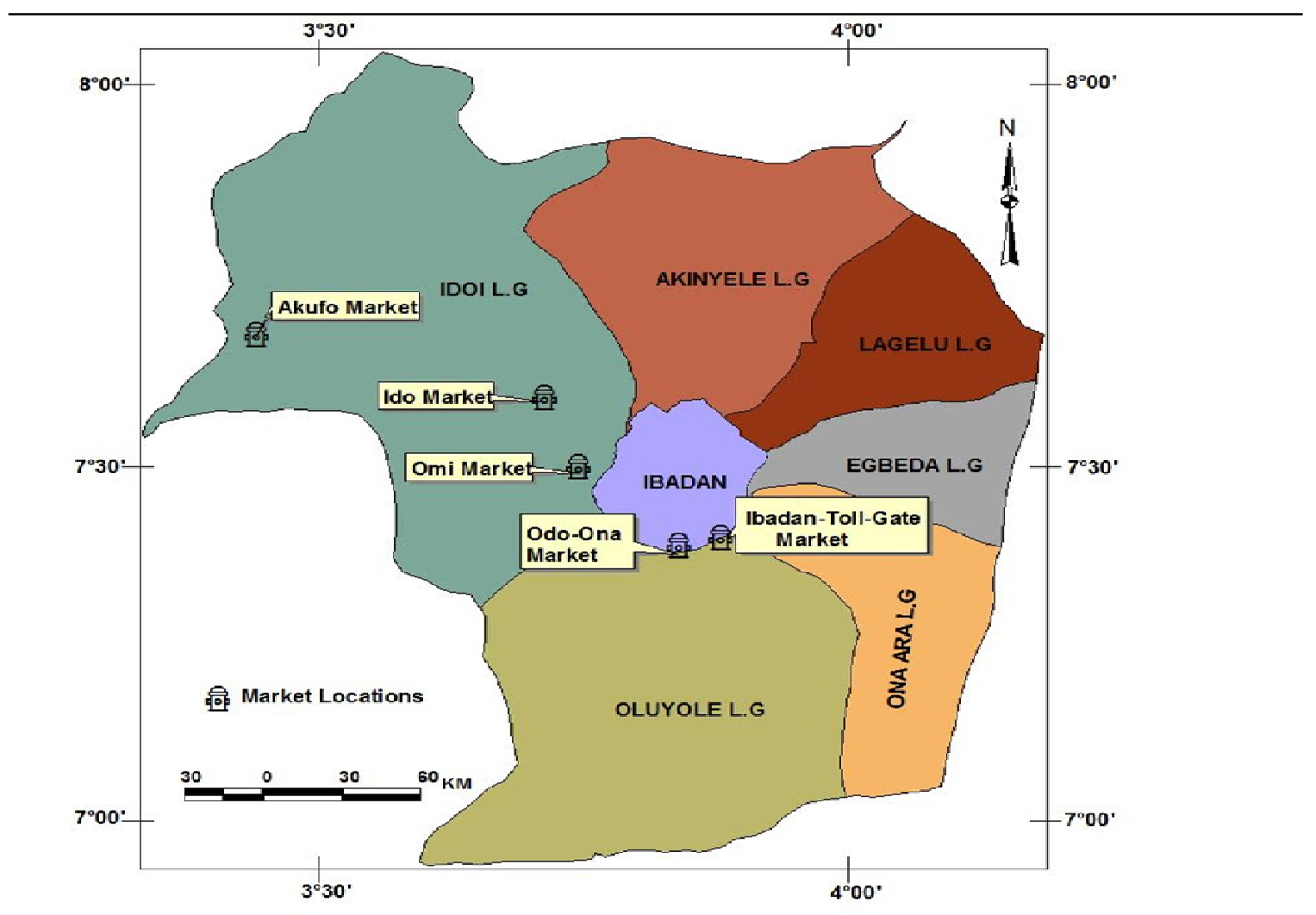

Figure 1: Map Showing the Locations of the Study Areas

\section{Sample size}

Five (5) prominent bush meat markets in Ibadan and its suburb (Figure 1) were used for this study. The selection was based on the intensity of bush meat marketing operations. All sellers in each market visited were interviewed which sum up to forty four respondents. Data were collected using structured questionnaire. Names of the five markets visited are:

Ido bushmeat market

Ibadan Toll gate bushmeat market

O do-ona Kekere bushmeat market

O mi-adio bushmeat market

Akufo bushmeat market.

\section{Data Analysis}

D escriptive statistics were used in analyzing socio-economic characteristics of bush meat sellers at the study areas. Also, budgetary analysis was used to calculate costs and return of the bushmeat sellers.

Gross Revenue $(G R)=$ Total output $\times$ Price per unit product-

$\mathrm{TC}=$ Total Cost Incurred (comprising Total Variable Cost (TVC) and Total Fixed Cost (TFC)

Gross Profit (GP) = GR - TVC---------(2)

Net Profit (NP) = GP - FC----.---(3)

Rate of return $(\mathrm{ROR})=\underline{\mathrm{TR}} \times 100$------ (4) $\mathrm{TC}$

Rate of Return on Investment $(\mathrm{RORI})=\underline{\mathrm{TR}}$

- TC $\times 100$ -

TC

Capital Turn Over $(\mathrm{CTO})=\frac{\mathrm{GR}-\cdot-\cdot-\cdot-\cdot}{\mathrm{TC}}$

Profitable Index $(\mathrm{PI})=\frac{\mathrm{GP}}{\mathrm{GR}}$ 
Net Bushmeat Income (NBI): this will be $(54.5 \%)$, this is in line with the findings of used to assess the performance level (profit Bifiran $\notin$ al. (2008) which states that majority wise) of the respondents; the net bushmeat of the marketers of bush meats were male in income is given as:

a bush meat markets of Ondo state. Also, $\mathrm{NBI}=\mathrm{TR}-\mathrm{TC}$

Where NBI = Net Bushmeat Income

\section{RESULTS AN D DISCUSSION Demographic Characteristics of Respondents} majority $(54.5 \%)$ of the respondents involved in the sales of bush meat in the study area had no formal education. This contradict the findings of Adedapo and Adekunle (2013) which state that majority (76.7\%) of those involved in the sales of bush meat in

The study reveals (Table 1 ) that majority of the respondents involved in the sales of South-Eastern Nigeria had tertiary educabush meat in the study area were male tion.

Table 1: Demographic Characteristics of Respondents

\begin{tabular}{llll}
\hline Characteristics & Frequency & Percent age & Mode \\
\hline Age & 8 & 18.2 & \\
$\leq 30$ & 18 & 40.9 & 40.9 \\
$31-40$ & 10 & 22.7 & \\
$41-50$ & 8 & 18.2 & \\
51-60 & 44 & 100 & \\
TOTAL & & & \\
Gender & 24 & 54.5 & 54.5 \\
Male & 20 & 45.5 & \\
Female & 44 & 100 & \\
TOTAL & & & \\
Marital Status & 1 & 2.3 & 97.7 \\
Single & 43 & 97.7 & \\
Married & 44 & 100 & \\
TOTAL & & & \\
Tribe & 43 & 97.7 & \\
Yoruba & 1 & 2.3 & \\
Igbo & 0 & 0 & \\
Other ethnic group & 44 & 100 & \\
TOTAL & & & \\
Place of Origin & 33 & 75 & \\
Oyo & 11 & 25 & \\
Others & 44 & 100 & \\
TOTAL & & & \\
Educational Background & & 54.5 & \\
No formal education & 24 & 31.8 & \\
Primary education & 14 & 11.4 & \\
Secondary education & 5 & 2.3 & \\
Tertiary education & 1 & 100 & \\
TOTAL & 44 & & \\
\hline
\end{tabular}


ECONOMIC CONTRIBUTION OF WILDLIFE TO BUSHMEAT MARKETS IN ..

Bush Meat Market and Livelihood Activities

Table 2 shows the annual income from the various classes of wild animals in each market. O do-O na Kekere market recorded the highest annual income $\$ 1,636,000$ from the sales of roasted wild mammals followed by Ido market $\$ 1,363,200$ per year also from the sales of roasted wild mammals. In all, income on mammals had the highest annual income $(\$ 5,755,600)$ followed by the income on bird roasting ( $\$ 858,000$ per annum) and reptile roasting (\$182,000 per annum). In the same pattern however, percentage contribution indicates (Table 3) that mammals contributed $84 \%$ of the total income, while wild birds contribute $12 \%$ of the total income and reptile $3 \%$.

Table 2: Distribution of Respondents by Markets and Class of Wild Animals Involved

\begin{tabular}{lclll}
\hline Market Name & $\begin{array}{l}\text { No of } \\
\text { Respon- } \\
\text { dents }\end{array}$ & $\begin{array}{l}\text { Income on } \\
\text { Roasted Birds } \\
\text { (\$)/ year }\end{array}$ & $\begin{array}{l}\text { Income on } \\
\text { Roasted Reptiles } \\
\text { (\$)/ year }\end{array}$ & $\begin{array}{l}\text { Income on Roasted Mam- } \\
\text { mals( } \mathbf{( \$ )} / \text { year }\end{array}$ \\
\hline Akufo & 9 & 160,000 & ---- & 971,200 \\
O do-Ona Kekere & 11 & 153,200 & --- & $1,636,000$ \\
Ibadan Toll Gate & 7 & 188,000 & $\overline{1} \overline{8} \overline{2}, 000$ & $1,030,000$ \\
Ido & 12 & 358,000 & & $1,363,200$ \\
O mi & 5 & & 182,000 & 755,200 \\
Total & 44 & 859,000 & & $5,755,600$ \\
\hline
\end{tabular}

Table 3: Proportions of Eamings and Income Shared by Source

\begin{tabular}{llll}
\hline Market Name & Birds Proportion & Reptiles Proportion & $\begin{array}{l}\text { Mammals } \\
\text { Proportion }\end{array}$ \\
\hline Earnings & & & 0.17 \\
Akufo & 0.19 & - & 0.28 \\
Odo-Ona Kekere & 0.18 & - & 0.02 \\
Ibadan Toll Gate & 0.22 & $\overline{-}$ & 0.24 \\
Ido & 0.42 & - & 0.13 \\
Omi & $\overline{1}$ & & 0.84 \\
Total & 1.01 & - & 0.14 \\
Total income & & - & 0.24 \\
Akufo & 0.02 & $\overline{-}$ & 0.15 \\
Odo-Ona Kekere & 0.02 & $\overline{0}$ & 0.20 \\
Ibadan Toll Gate & 0.03 & $\overline{0.03}$ & 0.11 \\
Ido & 0.05 & & 0.84 \\
Omi & $\overline{0.12}$ & & \\
Total & & & \\
\hline
\end{tabular}


Table 4 shows that the sales of mammals have contributed more to the selected markets than others classes of wild animals. Gross profit of $\$ 4,989,300$ was recorded for mammals in a year at the study area. This value corroborate the findings of O keke \& al. (2013), which recorded a gross profit of 11,996,230 within four months on the sales of mammal in Amansea. The net profit realized from the sales of mammals was $\$ 4,979,000$ and that of birds was
\#180,900. The difference in net profit can be attributed to the number of respondents involve in the sales of each category of wild animals and also the quantity sold per annum. Respondents involved in the sales of mammals make the highest income as indicated by the net profit per respondent ( $\$ 142,257)$, while respondents involved in the sales of birds had the least income ( 25,843$)$.

\section{Table 4: Cost and Retum Analysis}

\begin{tabular}{|c|c|c|c|}
\hline $\begin{array}{c}\text { DESCRIPTION } \\
\text { No of O bservations }\end{array}$ & $\begin{array}{c}\text { BIRD S ROAST- } \\
\text { ING } \\
7 \\
\text { \# }\end{array}$ & $\begin{array}{c}\text { REPTILES } \\
\text { ROASTING } \\
2 \\
\end{array}$ & $\begin{array}{c}\text { MAMMALS ROASTING } \\
35 \\
\text { a }\end{array}$ \\
\hline Gross Annual Return & 304,000 & 234,000 & $5,728,500$ \\
\hline $\begin{array}{l}\text { (unit price } \times \text { quantity) } \\
\text { VARIABLE COST }\end{array}$ & $(500 \times 600)$ & $(1000 \times 234)$ & $(1,500 \times 3,819)$ \\
\hline Fire wood & 67,200 & 19,200 & 336,000 \\
\hline Tax/ Permit & 22,400 & 6,400 & 112,000 \\
\hline Transportation & 23,200 & 16,000 & 291,000 \\
\hline $\begin{array}{l}\text { Total Variable Cost } \\
\text { (TVC) }\end{array}$ & 112,800 & 41,600 & 739,200 \\
\hline Gross Profit (GP) & 191,200 & 191,400 & $4,989,300$ \\
\hline FIXED COST & & & \\
\hline Shed & 6,500 & 6,500 & 6,500 \\
\hline Wire Mesh & 1,200 & 1,200 & 1,200 \\
\hline Knife & 300 & 300 & 300 \\
\hline Cutlass & 700 & 700 & 700 \\
\hline Bowl & 600 & 600 & 600 \\
\hline Aro & 1,000 & 1,000 & 1,000 \\
\hline Total Fixed Cost (TFC) & 10,300 & 10,300 & 10,300 \\
\hline D epreciation & 1,030 & 1,030 & 1,030 \\
\hline $\begin{array}{l}\text { Total Cost (TC) } \\
=\text { TVC+TFC }\end{array}$ & 123,100 & 51,900 & 749,500 \\
\hline Net Profit (NP) $=$ GP-FC & 180,900 & 181,100 & $4,979,000$ \\
\hline NP/ Respondent & 25,843 & 90,550 & 142,257 \\
\hline Benefit Cost Ratio & $1.6: 1$ & $3.7: 1$ & $6.7: 1$ \\
\hline $\begin{array}{l}\text { Profitability Index=GP/ } \\
\text { GR }\end{array}$ & 0.6 & 0.8 & 0.9 \\
\hline $\begin{array}{c}\text { RORI }=\text { Profit } \times 100 \\
\text { TC }\end{array}$ & 155.3 & 368.8 & 665.7 \\
\hline
\end{tabular}


ECONOMIC CONTRIBUTION OF WILDLIFE TO BUSHMEAT MARKETS IN ..

\section{CONCLUSION AND RECOMMENDATION}

The study has given information on the economic contribution of the various classes of wildlife to bushmeat market in Ibadan and its suburbs. The costs and return analysis showed that sale of bushmeat is a profitable venture. In addition, mammals contributed more to the economy of the market than the other two classes of wild animals in the bushmeat market. However, bushmeat market being a profitable business, awareness about the danger of indiscriminate harvesting of bushmeat is needed in the study area to sensitize both the hunters, sellers and the public on type and categories of animal to trade with.

\section{REFERENCES}

Adedapo, A.A and Adekunle, A.0. (2013). Economic aspects of Grasscutter Farming in Southwest Nigeria: Implications for Sustained Adoption and Conservation. Vol 4, issue $10 \mathrm{hhtp} / /$ urwrresch gatent/ publication/ 266947256.

Ajayi, S.S. (1971). Wildlife as a source of protein in Nigeria: Some Priorities for Development. Niggian Fidd36:115 - 127

Ajayi, S.S. (1979). Utilization of forest wildlife in West Africa. Misc/ 79/26. Organization des Nation Unies pour l'alimentation et l'agriculture, Rome, 79pp.

Ajayi, S.S. and Tewe, 0., 1983. A quantitative assessment of wildlife and their nutritive value as a source of food in Nigeria. In Akinyele, L. et A tome, T. (eds.) Nutrition and Food policy in Nigeria. National institute for Policy and Strategic Studies (NIPSS), Ibadan, Nigeria, pp. 138-148.

Ape Alliance (1998). The African Bush meat Tade - A recipe for Extinction. http// unw4tapescom/ bushment/ repart/ hushmeat.pof

Asibey, E.0.A (1977). Expected Effects of Land-Use Pattern on Failure Supplies of Bushmeat in Africa South of the Sahara. Enir. Cons 4, 43-49.

Bifarin, J.0., Ajibola, M.E. and Fadiyimu, A.A. (2008). Analysis of Marketing Bushmeat in Idanre Local G overnment A rea of Ondo State, Nigeria. Vol 3(10), pp 667671. hlth// unwracadanicjaumalsarg/ AJAR Brashares, J.S., Archase, P., Sam, MK., 2001. Human demography and reserve size, Predict wildlife extinction in West Africa. Proceeding of the Royal Society of London series B 268, 2474-2478.

Cowlishaw, G., Mendelson S. and Rowcliffe J.M. (2004) evidence for postdepletion sustainability in a mature bushmeat market. Jaumal of AppliedEodogy 42:460-468.

Decker 0 (2003). Agricultural economics and marketing of Wildlife in the Tropics. Longman Group UK Ltd. p.60.

Falconer, J., 1990. The major significance of "minor" forest products. Community Forest Note 6. Food and Agriculture Organization, Rome, 232pp.

Falconer, J., 1992. People's Uses and Trade in Non-timber Forest Products in Southern Ghana: A Pilot Study. Report prepared for the overseas development administration.

Guy, C., Samantha, M., Rowcliffe, JM., 2004. Structure and operation of a bush meat commodity chain in south western G hana. Conservation Bidogy18, 139-149.

Hoffman, L. C. 2008. The yield and nutritional value of meat from African ungulates, 
O.O. ODUNTAN, J.A. SO AGA A.L.A. SHOTUYO, O .A. AKINTUNDE AND T.O . O LAREWAJU

camelidae, rodents, ratites and reptiles. Meat on Giant Land Snail (NeGALS). Abiona and Science 80:94-100. O sunsina (Eds): 118-121. A Publication of

Malaisse, F. and Parent, G., 1982. Rodents of the Miombo Woodland Area: a Okeke, J.J., Umeaniebue, A.C., Ufele, nutritional and ecological approach. Eøogy A.N., Mogbo, T.C. and Nwosu, M.C. of FoodandNutrition, 11:211-216.

(2013). Evaluation of Hunters' Returns on Major Bushmeat Species in Amansea and its

Oates, J. M. Abedi-Lartey, W.S. Environs, South Eastern Nigeria. Vol 1(7), 5 McGraw, T.T. Struhsaker and G.H. -9. unww Iscain

Whilesides (2000) Extinction of a West

African Red Colubus monkey. Conservation Samantha, M., Guy C., and Rowcliffe , Bidogy. 14:1526-1532.

J.M., 2003. Anatomy of a bush meat com-

Oduntan 0.0., A.L.A. Shotuyo, A.F. Akmodity chain in Takoradi, G hana. TheJaumal inyemi, I.0.0. 0 sunsina and A.I. Ayodele (2014): Comparison of E conomic Feasibility and Sensory Characteristics of Giant Land Snail with Selected Bushmeats. Prowet

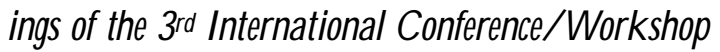
of Peasant Studies 31, 73-100.

Wilkie, D.S. and Carpenter, J.F. (1999) Bushmeat Hunting in the Congo Basin; an assessment of impacts and options for mitigation. Biodvesityand Conservation8: 927-955

(Manuscipt reecived 14th April, 2015; accepted 1st June, 2016) 